\title{
踵骨々折に対する腓骨遠位端切除術の小経験
}

$\begin{array}{rllllll}\text { 九州労災病院 } & & & & & \\ \text { 野 } & \text { 村 } & \text { 茂 } & \text { 治・岩 } & \text { 淵 } & & \text { 亮 } \\ \text { 佐 } & \text { 藤 } & \text { 護 } & \text { 彦・楊 } & & \text { 国 } & \text { 雄 } \\ \text { 香 } & \text { 月 } & \text { 一 } & \text { 朗・加 } & \text { 茂 } & \text { 洋 } & \text { 志 }\end{array}$

\section{Excision of the Tip of the Lateral Malleolus for the Crush Fracture of the Calcaneus}

By

\author{
S. Nomura, A. Iwabuchi, M. Sato, K. Yho, \\ I. Katsuki and Y. Kamo \\ Department of Orthopedic Surgery, Kyushu Rosai Hospital
}

In a severe crush fracture of the calcaneus, part of the lateral cortex may be displaced to lie under the lateral malleorus.

This may cause local pain and tenderness either by direct bony contact or by compression of the peroneal tendons.

Previously the surgical treatment of the complication has been excision of the displaced bone. However, in this way a trouble of calcaneal width does not improve. Excision of the tip of the latcral malleorus by ISBLSTER (1974) is good procedure in this condition.

In our cases, five of the six patients reported were completely relieved of lateral pain.

臨骨骨折後の疼痛は頑固でその治療に難淽するとと が多い.ての痛みの原因として距骨下関節の破壊によ るものが考えられ，てれに対して種々の治療法が報告 されている．しかし柏木が報告する如く，後関節面の 破壊により骨体部外側骨皮質の破壊がある場合，ての 骨片は外側に向って突出し転位癒合する．ての為ての 部を走っている腓骨筋腱に障碍与えまた，腓腹神経に 損傷を起す原因となる．今回われわれは ISBISTER の報告を参考にして腓骨遠位端部分切除を行ない, い ささかの知見を得たので報告する.

対象 : 腓骨遠位端の後方より下方にかけて骨性の膨
隆を触れ，ての部に自発痛，圧痛が著明であるもの， 腓骨筋腱腱㤔炎があり, 前後レ線で骨性膨隆が腓骨遠 位端に接近していると考えられる6 例を対象とした。 内訳は表 1 の如くで症例 6 を除き全て他医で処置を受 けた陳旧例である．今回の手術までの期間は 3 力月よ り 4 年である. 術後経過観察期間は平均 6 力月と短い が， 6 例中 5 例に術前の強い外側部痛は消失した.

手術方法：腓骨に沿った縦切開または腓骨下端を通 る弓状切開を用いた，骨膜下に腓骨遠位端後方部を斜 めに切除し, 距骨との関節面は温存する. 写真 1 の黒 くぬった部分である．踵骨外側に不整骨棘があれば除

表

1

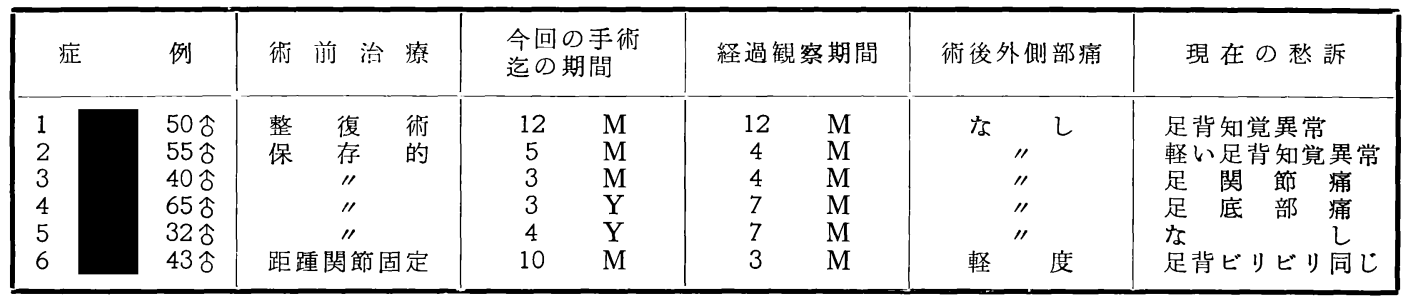


去し，腓腹神経に癒着および压迫があれば神経剝離術 を加えた。術後 1，2 週の安静後ホットパック,バイ ブラバスを利用した後療法を行なっている，症例を供 覧する。

症例 1.50 才, 機械工.

バイク走行中に転倒し受傷，足関節果部骨折を合 併, 跬骨は整復術を受ける。しかし1年後も外果部に 腫脹強く, 歩行時外果後縁より下端にか子て強い疼痛 があるため来院. 初彭時レ線では Böhler 任の減少と 踵骨の距骨下関節面の不整硬化像がある。な敃脛骨後 果部がわずかに転位癒合している（写真 2 ）。杣写レ 線では明らかに外果に接して 異常骨片をみる（写真 3). 手術時の所見は統腓骨筋腱腱制は肥厚し萁色在 呈している．膨隆し不整骨欶がある跌骨と腓骨下端の 間に腓骨筋腱が挾まれ，腓骨端と小骨片の接触もみら れた，腓骨遠位端後方の部分切除に加え腱鹤周囲の骨 棘を切除した。術後 1 週目にギプス除去, 歩行訢可す る.術前の激しろ疼痛は消失した。しかし手術時に損 傷した腓腹神経領域に知覚障碍を残した。 3 力月後現 職に復帰した（写真 4 ）。

症例 3.40 才, 会社員, 農家.

$2 \mathrm{~m}$ 半の高さより飛び降りて受傷. 10 週間ギプス 固定を受ける。後療法に移るも疼痛強く, 起立位も出 来状態である，受傷後 3 力月目に来院，蹈骨外側の腫 脤圧痛が著明で，レ線では変形矯正が不十分である上 Sudeck の骨萎縮が強い，痛みの原因として骨萎縮に
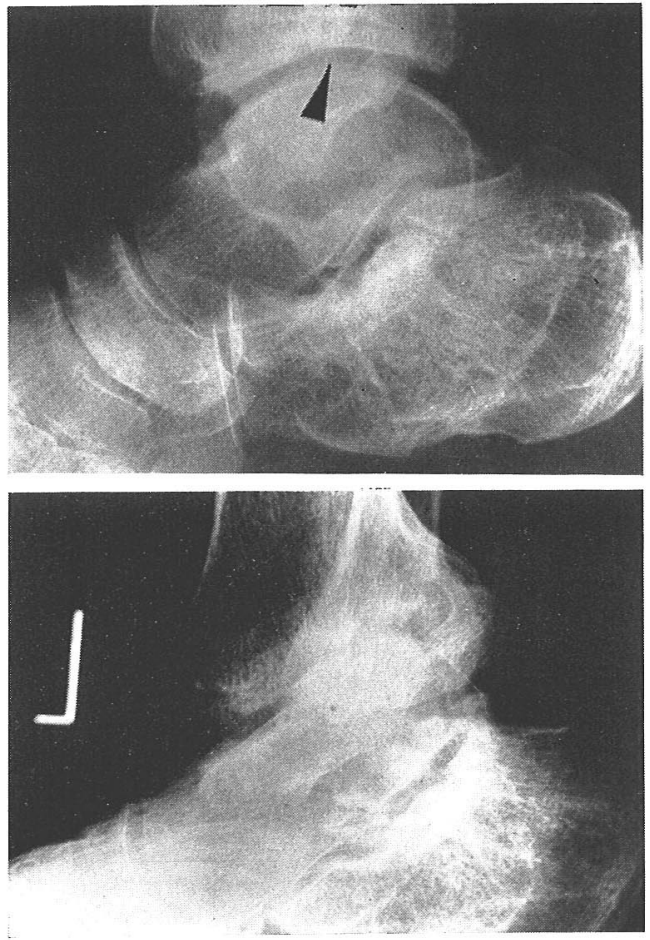

写真2 症例 $1:$ 初診侍 受傷後 $12 \mathrm{M}$

よるものがまず考えられるが外反位での疼痛の増強, 腱絛内の局麻剂注入による疼痛の軽減, レ線での外側 骨皮質の破畗膨隆所見より手術を行なった。術後は外
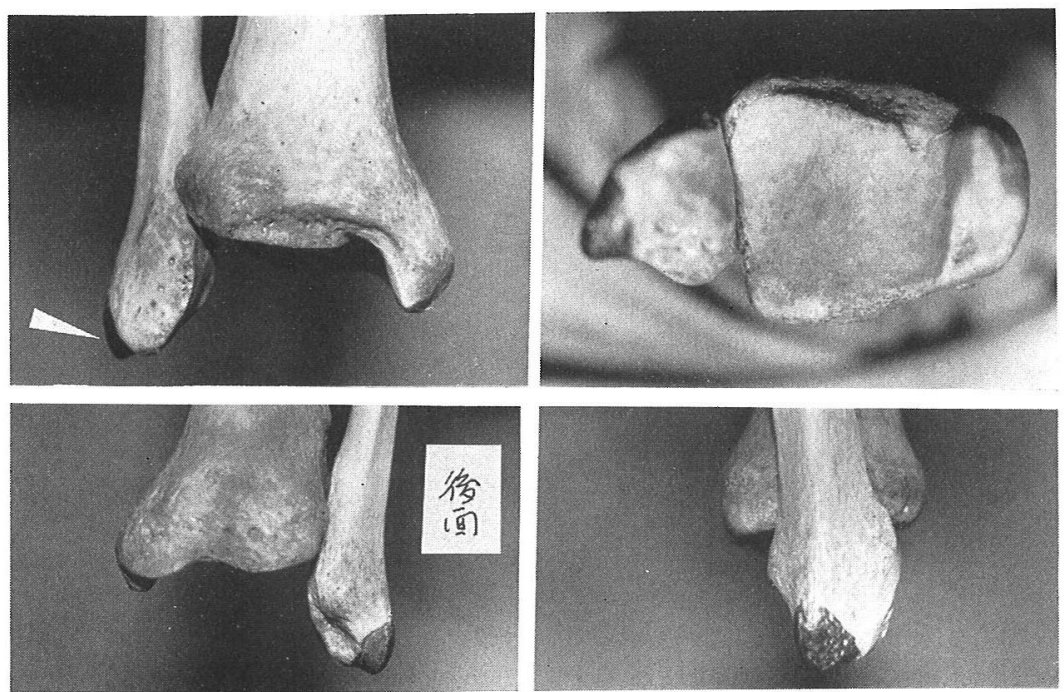

写真 1 腓骨遠位端切除部位 


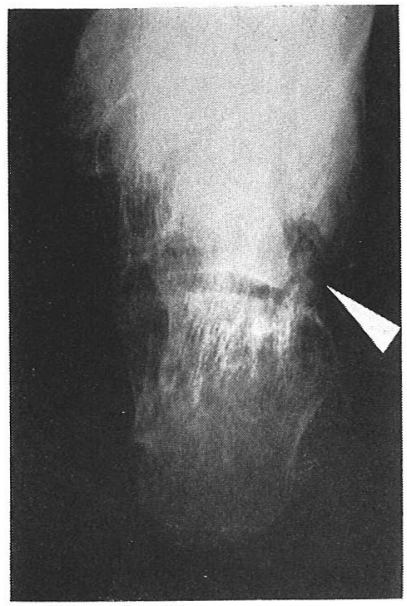

写真 3 症例 1

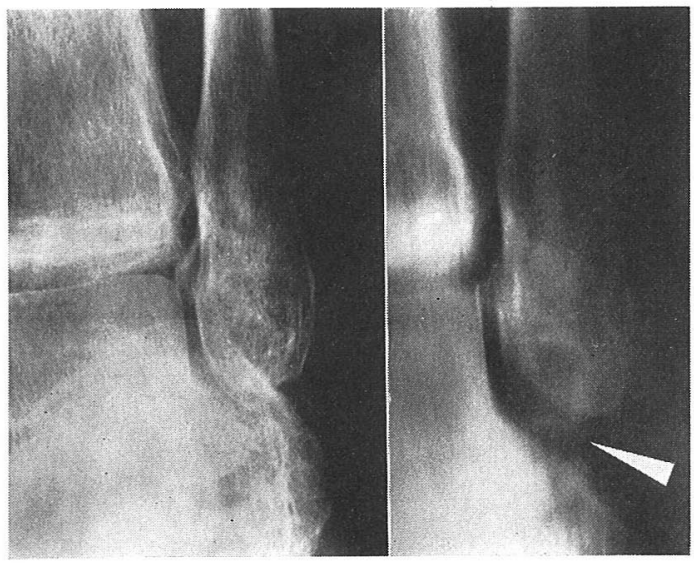

初揨特断属写真

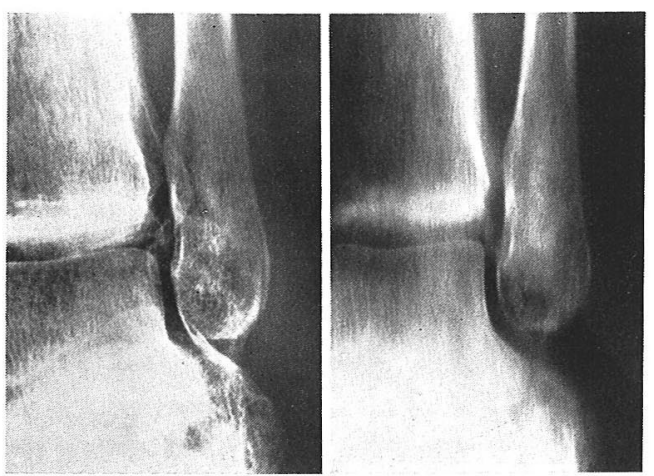

写 真 4

側部の強い痛みは消失, 立位もとれ後療法はスムース に行えた。術後 4 カ月, 足関節前方に軽度の痛みを訴 えた。術後 4 力月, 足関節前方に軽度の痛みを訴える が田稙も行っている.

症例 4.65 才, 男性, 卜ビ職.

$4 \mathrm{~m}$ の高さより転落, 大腿骨骨折を合併。距咀は 6 週間ギプス国定を受ける. 受傷後 3 年たつもなお距骨 外側部の腫脤疼痛が市るため来院・レ・線で距骨下関節 の破壞があるが，腓肯遠位端の後方より下方治い压

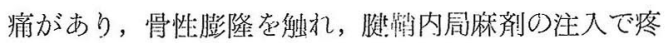
痛の軽減をみたので遠位犝部分切除に加气て骨欶除去

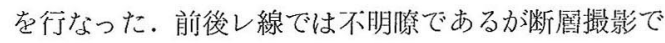
比較すると差異力はっきりする，現在足空部痛力゙残存 するが，これは足底部の䯚棘形成に起因するものと考 えている.
症例 6.43 才, 大工.

$3 \mathrm{~m}$ の高さより転落, 第 2 腰椎圧迫骨折を合併, 受 傷時より当科にて治療䯨行なう。骨折型は Arnesen の分類では Stamp type に属する. スタインマンピ

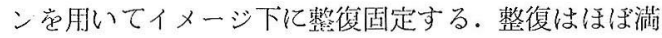
足のいく状態であった。しかし足部外側て连動痛が持 結するため 1 年半後距腫関節固定術蓬行なう。この際 腓腹神経を椇甥した，術後足底板を使用するも腓骬筋

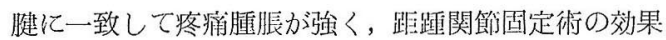
はみられなかった。術後 9 力月目に张釷と遠位端部分 切除，骨棘除去を行なう。術後踵骨外側部痛は軽減し たが現在，腓腹神経領域にビリビリする痛みと，踵立 方関節に疼痛を残す。
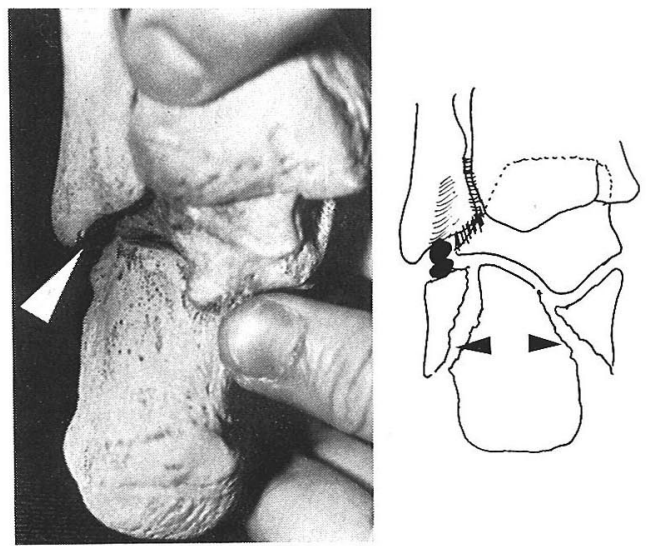

写 真 5 


\section{考察}

踵骨骨折後の疼痛の原因として, (1)距骨下関節, 時 にはChopart 関節の不適合, (2)扁平足障碍, 踵骨荷 重面の骨棘形成, (3)跬骨外側への骨突出に上る腓骨筋 腱の障碍によるものがある，些際にはこれ等の原因が 相合さって症状を起す訳で，どの因子がいが関与し ているか見きわねばならない，外側への骨突出による

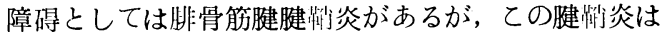
屚平足に加えて距骨下関節の可動不全によっても起り うる訳で，表 2 亿示す如き所見がきめてとなる。レン トゲンで非骨下端と距骨との接触があれば確実である が Böhler 角の減少等で跬骨後方部分と腓骨下端が重 なる為明確にうつし出されない場合もある. 手術時期

表 2 彮断及び手術適応

1. 踵骨の横径軸の㹡大

2. 腓骨遠位端の後方より下方に骨膨隆を触れる

3. 同部に腫脹王痛が著明

4. 腓骨筋腱々鞘内の局麻剂注入により疼痛の軽 減

5. 外反位で疼痛が増強

は所見があれば $3 ， 4$ 力月の比較的早期に行なっても 良いと考えている。

従来外側の骨突出に対しては障碍部の骨切除が奖め られている.しかし䠐骨全体が横広がりに変形し, そ れにより腓骨後方より下端を通る腓骨筋腱を圧迫する 訳で不整骨棘のみの切除では除圧は不十分であり, こ こに腓骨遠位端部分切除の意義がある（写真 5 ）. ISBISTER は部分切除のみで良いとしているが不整 な骨棘は滑膜炎の原因になると考え除去している.
合併症としては腓腹神経の損傷があるが注意すれば さけられるものである。

終りに, 踵骨骨折後の疼痛の原因として従来あまり に距骨下関節の破壊が強調されてきた。しかし柏木が 強調する様に外側骨皮質の破壊による障碍もある．現 在てれに対する治療法は始息的であったと言える．今 回腓骨遠位端部分切除を行なったが，この手術は古く 1907 年に Cabot and Binney より報告されている. 簡単な手術で侵襲も少なく，短期間に症状の改善をみ るととが出来たので報告する．

（稿を終るにあたり，ご校閲を頂いた天児民和先生 ならびに御教示頂いた鳥巣岳彦先生に深謝いたしま す.)

参考文 献

1）柏木大治：踵骨々折の診断と治療. 整形外科. $15,1213-1229,1964$

2）川島信二・他：踵骨々折後の外果下部痛の治療 経験, 日災医誌, 24, 252-255, 1976.

3) John F. St. C. Isbister, Calcaneo-fibular abutment following crush fracture of the calcaneus, Journal of Bone and Joint Surgery, 56-B, 274-278, 1974.

質 問長崎大 鈴木 良平 靶帯はごう処理されますか.

解 答菠学災

靮帯すなわち Talofibular, calaneofibular ligament は骨膜下に処理するため，䩒帯は損傷しない. 靿帯は腓骨節腱より内側にある。 